\title{
Integrated Grazing and Prescribed Fire Restoration Strategies in a Mesquite Savanna: III. Ranch-Scale Cow-Calf Production Responses
}

\author{
W. E. Pinchak, ${ }^{1}$ W. R. Teague, ${ }^{1}$ R. J. Ansley, ${ }^{1}$ J. A. Waggoner, ${ }^{2}$ and S. L. Dowhower ${ }^{3}$ \\ Authors are ${ }^{1}$ Professors, ${ }^{2}$ Former Research Associate, and ${ }^{3}$ Senior Research Associate, Texas AgriLife Research, Vernon, TX 76385 , USA.
}

\begin{abstract}
Beef cattle production from rangelands in the Southern Great Plains has decreased in concert with herbaceous forage production declines in response to woody plant encroachment by honey mesquite (Prosopis glandulosa Torr.) over the past 120 yr. Combinations of livestock overstocking and fire suppression are considered to be primary drivers of these changes. This experiment evaluated cow-calf production responses over a 7-yr (1995-2001) period to ranch-scale (1294-2130 ha) integrated restoration strategies involving prescribed fire and grazing management. Restoration strategies tested in this year-round grazing ecosystem were 4-pasture, 1 -herd rotation with fire ( $25 \%$ of pasture acreage burned each year; 4:1F); an 8-pasture, 1 -herd rotation, with fire $(8: 1 \mathrm{~F})$; and a 4-pasture, 1 -herd, with fire and aerial application of $0.28 \mathrm{~kg} \cdot \mathrm{ha}^{-1}$ clopyralid $+0.28 \mathrm{~kg} \cdot \mathrm{ha}{ }^{-1}$ triclopyr herbicide $(4: 1 \mathrm{~F} / \mathrm{H})$. Restoration strategies were compared to a continuous grazing strategy with no mesquite treatment. All cattle stocking rates were moderate $\left(7.5-15 \mathrm{ha} \cdot\right.$ animal unit $\left.^{-1} \cdot \mathrm{year}^{-1}\right)$ and all fires were applied during late winter. Beef cattle (cow-calf) production variables measured included conception rate, weaned calf percentage, weaning weight, weight of calf per exposed cow, weight of calf per hectare, and supplement fed per cow. We observed significant differences in beef production among strategies primarily during the first $2 \mathrm{yr}$ where the continuous grazing strategy exhibited better overall livestock production than the integrated restoration strategies. Differences in livestock production among strategies were minimal over the last $5 \mathrm{yr}$ of the study. These livestock production results suggest livestock and management adapted to restoration strategies after the first 2 yr. Results point to the need to cautiously transition into integrated grazing and fire restoration strategies when cattle and management are changed and intensified from prior historical protocols.
\end{abstract}

\section{Resumen}

La producción de ganado de carne en los agostaderos de las grandes planicies del sur ha disminuido al igual que la producción de herbáceas forrajeras por el incremento de las plantas leñosas como mezquite (Prosopis glandulosa Torr.) en los últimos 120 años. La combinación del sobre pastoreo y la supresión del fuego se consideran las causas principales de estos cambios. Este experimento evaluó la respuesta de la producción vaca-becerro durante un periodo de 7 años (1995-2001) a la escala de un rancho (1294 a $2130 \mathrm{ha}$ ) usando las estrategias integradas de fuego pre-escrito y manejo del pastoreo. Las estrategias de restauración utilizadas en este ecosistema pastoreado continuamente fueron 4 potreros/ 1 hato con rotación y uso de fuego (quemamos el $25 \%$ del área cada año; 4:1Q); y 8 potreros/ 1 hato con rotación y uso del fuego (8:1Q); y 4 potreros, 1 hato con quemas y aplicación aérea de $0.28 \mathrm{~kg} \mathrm{ha}^{-1}$ de clopyralid + de $0.28 \mathrm{~kg} \mathrm{ha}^{-1}$ de triclopyr (4:1Q/H). Las estrategias de restauración se compararon con una estrategia de pastoreo continuo sin tratamiento de mezquite. Toda la carga animal fue moderada (7.5 a 11 ha/AUA) y todas las quemas se hicieron en la parte final del invierno. Las variables de producción de ganado que se midieron fueron, índice de concepción, porcentaje de becerros destetados, peso al destete, peso del becerro por vaca expuesta, peso del becerro por hectárea y suplemento utilizado por vaca. Se observaron diferencias significativas en la producción de carne entre estrategias; principalmente durante los dos primeros años donde la estrategia de pastoreo contínuo presenta en general mejor producción de ganado que las estrategias integradas de restauración. Las diferencias en la producción ganadera entre estrategias fueron mínimas durante los últimos 5 años del estudio. Estos resultados de la producción de ganado sugieren que el ganado y manejo se adaptaron a las estrategias de restauración después de los 2 primeros años. Los resultados señalan la necesidad de una transición con cautela en la integración de la restauración utilizando las estrategias del fuego y pastoreo cuando se cambia el ganado y el manejo comparando con protocolos anteriores.

Key Words: brush management, cattle, Prosopis glandulosa, ranch-style grazing management, ranching systems, rangeland restoration

Funding was provided by the E. Paul and Helen Buck Waggoner Foundation, Inc.; the US Department of Agriculture, National Research Initiative Competitive Grants Program Agricultural Systems Grants 9404256 and 98-35108-6491; Dow AgroSciences, Indianapolis, IN; the North Texas Brush Control Association, Albany, TX; and Texas AgriLife Research. The E. Paul and Helen Buck Waggoner Foundation, Vernon, TX, provided land area and cattle for the project.

Correspondence: W. E. Pinchak, Texas AgriLife Research, PO Box 1658, Vernon, TX 76385, USA. Email: w-pinchak@tamu.edu

Manuscript received 21 July 2008; manuscript accepted 19 December 2009.

\section{INTRODUCTION}

Shifts in Southern Great Plains of the United States rangeland ecosystems from predominantly grasslands to mixed woodlands and savannas over the last $120 \mathrm{yr}$ has been attributed variously to inappropriate stocking rates, fire suppression, enhanced distribution of woody plant seeds, and increased atmospheric $\mathrm{CO}_{2}$ (Archer et al. 1995; Van Auken 2000; Asner 
et al. 2003). Livestock carrying capacity has declined as grass forage production has been reduced due to woody plant encroachment, primarily honey mesquite (Prosopis glandulosa Torr.). Increasing abundance of this woody plant complicates management actions such as animal movement, health monitoring, and supplemental feeding (Bedunah and Sosebee 1984).

Fire can top-kill mesquite and temporarily improve livestock carrying capacity by restoring productivity of herbaceous vegetation (Wright and Bailey 1982; Ansley and Jacoby 1998; Ansley and Castellano 2007). For fire to be effective in reducing cover of mature mesquite trees, grazing must be deferred for a period of time to accumulate sufficient herbaceous fine fuel (i.e., grass) not only to carry a fire, but to have it be of sufficient intensity to reduce woody cover (Wright and Bailey 1982; Scifres and Hamilton 1993; Ansley et al. 1998). However, because fire only suppresses and does not kill mature mesquite, a management strategy that uses fire must also provide a means for repeated burning to maintain suppression.

Although many studies have been conducted in the Southern Great Plains to quantify herbaceous responses to woody plants or to fire (McDaniel et al. 1982; Ansley et al. 2004; Ansley and Castellano 2007; Teague et al. 2008a), the relationships of these responses to livestock performance have not been reported previously. The combined effects of grazing and fire on ecosystem processes increasingly are being investigated (Valone and Kelt 1999; Valone 2003; Fuhlendorf and Engle 2004; Archibald et al. 2005). However, the majority of published reports are based on measuring components of ecosystems at relatively small spatial scales that preclude estimation of livestock productivity responses. The preponderance of previous research investigating the effects of grazing strategies has focused on herbaceous species and livestock responses in grassland ecosystems that were not dominated by woody plants. Moreover, they have been conducted at spatial scales considerably smaller than many commercially managed rangelands in the Southern Great Plains (Heitschmidt et al. $1982,1990)$. We found no published research that investigated the integration of grazing strategies and prescribed fire for the purpose of increasing herbaceous fine fuel for fire to reduce woody plant cover, providing post-fire rest from grazing, sustaining livestock productivity, and restoring herbaceous vegetation.

The overall goal of this project was to integrate grazing and fire strategies at the landscape scale (1000-2000 ha) to concurrently reduce negative impacts of mesquite encroachment and maintain or improve herbaceous and beef cattle production. We evaluated the potential of one-herd, multiplepaddock grazing strategies to facilitate the application of prescribed fire for woody plant suppression through internalized grazing deferment, and simultaneously maintain or improve herbaceous and livestock (cattle) production. Given the annual precipitation level $(648 \mathrm{~mm})$ in our region, we estimated that $25 \%$ of the production area of a multipaddock system (1 paddock in a 4-paddock system or 2 paddocks in an 8-paddock system) could be burned, and cattle, stocked moderately for the entire system, could be temporarily concentrated on the remaining $75 \%$ of the system, under normal climatic conditions. Therefore, restoration strategies adopted were a 4-pasture, 1 -herd rotation with fire $(4: 1 \mathrm{~F})$ and an 8 -pasture, 1 -herd rotation with fire $(8: 1 \mathrm{~F})$. The 8:1F strategy was a more intensive rotation strategy than the $4: 1 \mathrm{~F}$ but also provided more flexibility in managing deferral to accumulate fine fuel (see Teague et al. 2010 for more details). The fire and grazing restoration strategies were compared to a continuous grazing strategy with no mesquite treatment (Cont).

In addition to the $4: 1 \mathrm{~F}$ and $8: 1 \mathrm{~F}$ restoration strategies, we included a third restoration strategy: a 4-pasture, 3-herd rotation with fire $(4: 3 \mathrm{~F})$ at the request of our Rancher Advisory Committee, comprised of ranchers in north Texas, who felt that this would be the least intensive means of providing some grazing deferral for fire. This strategy later was changed to a 4pasture, 1-herd with fire and mesquite herbicide treatment $(4: 1 \mathrm{~F} / \mathrm{H})$ because drought in spring 1996 after the first-year fires were applied required drastic destocking and suggested that fire in a 4:3 fire strategy was not feasible. Herbicide inclusion into a 4:1 grazing strategy was chosen because aerial application of herbicide is commonly used for restoration of mesquite-dominated rangelands (McGinty 2004; Mitchell et al. 2004).

Data for this study are found in three papers; the first two focus on vegetation responses to the integrated grazing and fire restoration strategies and report conditions for the prescribed fires as well as fire intensities and effects (Ansley et al. 2010; Teague et al. 2010). The aim of this paper was to determine beef cattle production responses to the restoration strategies. In this paper we evaluate several cow-calf performance criteria. We hypothesized that under year-round grazing, restoration strategies that integrate grazing and prescribed fire 1) could reduce mesquite cover without adversely affecting animal performance, and 2) would allow both pre- and postfire deferment to be internalized within a grazing management unit when a ranch is fully stocked with cows and replacement heifers at a carrying capacity that is considered the norm for most commercial ranching enterprises in the region. Our specific livestock performance hypothesis was that at comparable year-long stocking rates, integrated grazing and fire or grazing and herbicide strategies would improve cow-calf performance compared to continuous grazing without mesquite control, because increasing mesquite cover would decrease animal performance.

\section{MATERIALS AND METHODS}

\section{Study Area}

The investigation was conducted in the Rolling Plains of northcentral Texas on the Kite Camp of the Waggoner Ranch (lat $33^{\circ} 50^{\prime} \mathrm{N}$, long $99^{\circ} 5^{\prime} \mathrm{W}$ ) near Vernon. The climate is continental with an average 220 frost-free growing days. Mean annual precipitation is $648 \mathrm{~mm}$, varying from $490 \mathrm{~mm}$ to $1000 \mathrm{~mm}$. It is bimodally distributed with peaks in May $(95 \mathrm{~mm})$ and September $(76 \mathrm{~mm})$. Mean monthly temperature varies from $2.3^{\circ} \mathrm{C}$ in January to $36.4^{\circ} \mathrm{C}$ in July. Elevation ranges from $335 \mathrm{~m}$ to $396 \mathrm{~m}$.

Honey mesquite trees dominated the vegetation at $9 \%$ to $31 \%$ canopy cover. Herbaceous vegetation was dominated by Texas wintergrass (Nassella leucotricha [Trin. \& Rupr.] Pohl.), silver bluestem (Bothriochloa laguroides [DC.] Herter. subsp. torreyana [Steud.] Allred \& Gould), sideoats grama (Bouteloua curtipendula [Michx.] Torr.), meadow dropseed (Sporobolus 
compositus [Poir.] Merr.), buffalograss (Buchloe dactyloides [Nutt.] J. T. Columbus), the annual Japanese brome grass (Bromus japonicus Thunb. ex Murr.), and forbs heath aster (Aster ericoides L.), common broomweed (Amphiachyris dracunculoides [DC.] Nutt.), and western ragweed (Ambrosia psilostachya DC.). The herbaceous vegetation is characterized by alternating shortgrass and midgrass patches with Texas wintergrass dominating under the canopies of mesquite trees (Teague et al. 2008a). Soils consisted of shallow clays (3\% to $8 \%$ slopes), moderately deep clay loams ( $1 \%$ to $3 \%$ slopes), and deep loamy bottomlands in riparian zones $(0 \%$ to $1 \%$ slopes). Ecological sites include Vernon Shallow Clay (RO78CY112TX), Tillman Clay Loam (RO78CY096TX), and Wheatwood Loamy Bottomland (RO78CY103TX; R. Quiett, Natural Resources Conservation Service [NRCS], Vernon, TX, personal communication, August 2009). Mesquite size, density, and cover were greatest on the clay loam soils. About $60 \%$ of annual primary production takes place in May and June.

\section{Restoration Strategies}

The experiment initially consisted of four landscape-scale strategies: 1) continuous grazing with no mesquite control (Cont.); 2) a 4-pasture, 1-herd rotation with fire (4:1F); 3) an 8pasture, 1 -herd rotation with fire $(8: 1 \mathrm{~F})$; and 4$)$ a 4-pasture, 3herd rotation with fire $(4: 3 \mathrm{~F})$. There were two replicates of each strategy (replicate size range: 1294-2130 ha), which is comparable to small- to mid-sized commercial ranches in the region. Strategies had a similar mix of soil types (see Ansley et al. 2010 for more details). Multipaddock strategies were crossfenced in 1995. Land area of individual paddocks was adjusted during fencing to yield similar herbaceous production potential among paddocks in each replicate.

The woody plant management goal in the fire-based strategies was to burn a different $25 \%$ of the area of each strategy each year. Fires were conducted in winter months (January-March) and were planned as high-intensity mesquite top-killing fires to maximize mesquite suppression. To accumulate herbaceous fuel on the $25 \%$ to be burned, cattle were rotationally grazed on the remaining $75 \%$ of each strategy for all or part of the 9 mo prior to burning (May-January) without a reduction in year-long stocking rate at the system level (see Teague et al. 2010 for more details). As a result, costs of deferral were internalized. Fire was to be used when average or above-average precipitation resulted in sufficient fine fuel $\left(>1500 \mathrm{~kg} \cdot \mathrm{ha}^{-1}\right)$ to suppress mesquite. During drought years, $12.5 \%$ rather than $25 \%$ of the system was burned, or deferred pastures were not burned but grazed as needed, depending on prevailing circumstances.

First burns were conducted in January-March 1996. Fires were applied as headfires that were burned into preburned blacklines (50 m wide) on downwind sides of each paddock (Wright and Bailey 1982). A severe spring drought following the 1996 fires forced discontinuation of the 4:3F strategy due to lack of forage, and in 1998, both replicates of this strategy were converted to 4-pasture, 1-herd rotation with aerial application of herbicide as the method of mesquite control $(4: 1 \mathrm{~F} / \mathrm{H})$. This strategy thus had a prescribed fire in one paddock in 1996 and herbicide aerial spray $\left(0.28 \mathrm{~kg} \cdot \mathrm{ha}^{-1}\right.$ clopyralid $+0.28 \mathrm{~kg} \cdot \mathrm{ha}^{-1}$ triclopyr; see Ansley et al. 2003, 2004, and 2010) in the other paddocks in 1999. Herbicide spray was concentrated on the clay loam soils where mesquite cover was greatest. For the remainder of this paper, this strategy will be referred to as the $4: 1 \mathrm{~F} / \mathrm{H}$ strategy.

\section{Livestock Grazing and Management}

Prior to research implementation, each experimental unit was a single pasture grazed by a single age class herd of commercial Hereford cows bred to Hereford bulls to calve from January through March. Cowherd age ranged from $3 \mathrm{yr}$ to $10 \mathrm{yr}$. Grazing was managed as year-round continuous grazing at a stocking rate of $12.1 \mathrm{ha} \cdot$ animal unit ${ }^{-1} \cdot \mathrm{yr}^{-1}\left(\mathrm{ha} \cdot \mathrm{AUY}^{-1}\right)$. At research implementation, we retained the same breeding season but each research herd was configured with equal proportions in each of the 3-8-yr-old age classes to minimize confounding of age and strategy and to better represent typical cowherd age structure in the region. All cows initially came from the existing herd units on Kite Camp and required sorting single age class herds into multiage class herds and reassigning these herds to units with which the majority of animals were unfamiliar. Stocking rate also was increased to $7.5 \mathrm{ha} \cdot \mathrm{AUY}^{-1}$ because this was a rate that was more typical of most ranches in the area (NRCS staff, personal communication, January 1995).

A stream, river, and earthen ponds were spatially situated so that all livestock grazing was within $1.2 \mathrm{~km}$ of water. The same free-choice mineral supplement was available year-round in all strategies. Supplements, as 39\% protein cubes, were fed every third day in winter to achieve a body condition score of 5 (1-9 scale) at the end of winter.

Calves were weaned and group-weighed by sex at the end of October each year. For each replicate herd, calves were sorted by sex, transported $26 \mathrm{~km}$, and group-weighed on certified truck scales. Cows were rectally palpated for pregnancy. Nonpregnant cows and cows with udder, feet, and eye problems were removed from a herd at weaning and replaced with pregnant cows (3 to $7 \mathrm{yr}$ of age, based on availability).

We used the The Grazing Manager (TGM) optical utilization score (scale 0 to 5; Kothmann and Hinnant 1999) to decide when to move animals in each rotation treatment replicate. Weekly visual assessments were made at 10 points in each paddock being grazed to determine the TGM utilization score and when the animals needed to be moved. First-year postfire grazing in burned paddocks was determined by observation of $\mathrm{C}_{4}$ midgrass growth; when these grasses reached $15-\mathrm{cm}$ height, paddocks were lightly grazed (TGM score $=1$; light use of highly palatable forage and negligible use of midpalatability forage) before animals were moved. For all paddocks that had not been burned the same year, animals were moved when utilization was adjudged as moderate (TGM score $=2$; moderate use of highly palatable forage, light use of midpalatability forage, and negligible use of low-palatability forage). The preferred palatable plants were Texas wintergrass (except in summer), sideoats grama, buffalograss, big bluestem (Andropogon gerardi Vitman), western wheatgrass (Pascopyrum smithii Rydb.), and little bluestem (Schizachyrium scoparium [Michx.] Nash). In practice, this resulted in periods of absence in paddocks of approximately $45 \mathrm{~d}$ and $90 \mathrm{~d}$ during fast and slow forage-growth periods, respectively. Animal management was otherwise the same among strategies. 
Table 1. Description of livestock performance variables measured.

\begin{tabular}{|c|c|c|c|}
\hline Variable & Acronym and units & Definition & Interpretive value \\
\hline Conception rate & CR $(\%)$ & Percentage of cows bred that were intended to be bred. & $\begin{array}{l}\text { Determines reproductive success within a year and } \\
\text { strategy. }\end{array}$ \\
\hline Weaned calf percentage & WC $(\%)$ & $\begin{array}{l}\text { Number of calves weaned in a calendar year divided by } \\
\text { the number of cows intended to be bred the calendar } \\
\text { year before and multiplied by } 100 \text {. }\end{array}$ & $\begin{array}{l}\text { An integrated measure of reproductive and survival } \\
\text { success to weaning. }\end{array}$ \\
\hline Weaning weight & WWT (kg) & $\begin{array}{l}\text { Total calf weight divided by number of calves weaned } \\
\text { within a year. }\end{array}$ & $\begin{array}{l}\text { The basis for comparing calf productivity among } \\
\text { strategies. }\end{array}$ \\
\hline $\begin{array}{l}\text { Weight of calf weaned to } \\
\text { exposed cow }\end{array}$ & WtPEC $(\mathrm{kg})$ & $\begin{array}{l}\text { Total calf weight divided by the number of cows } \\
\text { exposed to breeding in the previous year. }\end{array}$ & $\begin{array}{l}\text { Best index of overall productivity at the cow herd } \\
\text { level. }\end{array}$ \\
\hline $\begin{array}{l}\text { Weight of calf produced } \\
\text { per hectare }\end{array}$ & WtPHA (kg) & $\begin{array}{l}\text { Total calf weight divided by the number of hectares } \\
\text { in a replicate landscape. }\end{array}$ & $\begin{array}{l}\text { An unbiased index of productivity per unit land area. } \\
\text { Scales individual and cow herd productivity to the } \\
\text { land area utilized to sustain a cow herd and calves. }\end{array}$ \\
\hline $\begin{array}{l}\text { Supplemental feed and } \\
\text { mineral amounts }\end{array}$ & $\operatorname{SUPP}\left(\mathrm{kg} \cdot\right.$ head $\left.^{-1}\right)$ & Amount supplied by weight per head. & $\begin{array}{l}\text { Represents the major variable costs associated with } \\
\text { cow-calf production. Is sensitive to imbalances in } \\
\text { nutrient supply and nutrient demand associated } \\
\text { with any grazing strategy. }\end{array}$ \\
\hline
\end{tabular}

\section{Livestock Measurements}

The efficiency of beef production in cow-calf systems is the integrated expression of reproductive success, weaning success, mass of calf produced, mass of calf per cow intended to be bred, and the mass of calf produced per hectare (Arthington et al. 2007). The cost unit in a cow-calf production system is the cow. Over $95 \%$ of the costs to produce a kilogram of weaned calf are associated with successfully breeding and maintaining the cow to successfully wean a calf; therefore, the cow unit is an unbiased common denominator for comparing responses to management.

We selected livestock measures at the individual cow and calf level and at the land area allocated to each cow as response variables to restoration strategies. These variables included conception rate (CR), weaned calf percentage (WC), weaning weight (WWT), weight of calf weaned to exposed cow (WtPEC), weight of calf produced per hectare (WtPHA), and supplemental feed and mineral amounts (SUPP; Table 1).

\section{Statistical Analyses}

All indices of animal reproductive and individual performance and animal productivity per unit area were analyzed utilizing Proc Mixed procedures (SAS 2002), such that the model was $y=$ strategy, replicate, year, strategy $\times$ year; where replicate was a random effect. We chose to analyze year as a fixed effect instead of a random effect because we were interested in the strategy $\times$ year interaction as an indicator of strategy effected changes through time. Means were separated when $P<0.05$ utilizing the PDIFF algorithm for pairwise comparison.

\section{RESULTS}

\section{Precipitation, Fire History, and Stocking Rate}

The first year of the study, 1995, had growing-season precipitation that was well above normal (Fig. 1). Spring and summer of 1996 were exceptionally dry followed by a wet autumn. The first half of 1997 was close to normal followed by a dry autumn. The winter of 1997-1998 had above-normal precipitation; however, the rest of 1998 was very dry. Early summer of 1999 was wetter than average but late summer and autumn were drier than average. In 2000 and 2001 both summer and autumn rains failed.

Temperatures were close to the long-term mean $\left(17.3^{\circ} \mathrm{C}\right)$ in 1995 through $1997\left(16.9^{\circ} \mathrm{C}\right.$ to $\left.17.2^{\circ} \mathrm{C}\right)$ but above the long-term mean in 1998 through $2000\left(18.7^{\circ} \mathrm{C}\right.$ to $\left.18.8^{\circ} \mathrm{C}\right)$. The climatic conditions during this period were sufficiently droughty to force even moderately stocked ranchers to reduce stocking rates by $30 \%$ to $50 \%$. Ranchers in the region were eligible for drought relief assistance from 1996 through 2001 (Farm Service Agency, United States Department of Agriculture, Wilbarger County, Texas).

Droughts greatly limited fine fuel accumulation and the number of pastures we could burn. During the 5 -yr period from 1996-2000, two of four paddocks in each of the two 4:1F replicate strategies, four of eight paddocks in each of the two $8: 1 \mathrm{~F}$ replicate strategies, and one paddock in each of the two $4: 1 \mathrm{~F} / \mathrm{H}$ replicate strategies were burned. This total of 14 burned paddocks was less than half of the original 36 paddocks scheduled to be burned (Table 2; see Ansley et al. 2010 for more details).

Stocking rates were reduced uniformly in all treatment strategies from about $7.5 \mathrm{ha} \cdot \mathrm{AUY}^{-1}$ in $1995-1996$ to $11-$ $12 \mathrm{ha} \cdot \mathrm{AUY}^{-1}$ in $1997-1999$, and finally $15 \mathrm{ha} \cdot \mathrm{AUY}^{-1}$ in 2000-2001 following droughts (Table 2).

\section{Conception Rates}

There was no difference among strategies in conception rates in 1995 because cattle were bred during the early implementation phases of the strategies (Table 3). Among strategies, conception rate was lower $(P<0.05)$ in the $4: 1 \mathrm{~F}$ than $4: 1 \mathrm{~F} / \mathrm{H}$ strategy in 1996. From 1997 through 2001 there were no differences in conception rate among strategies within years. 


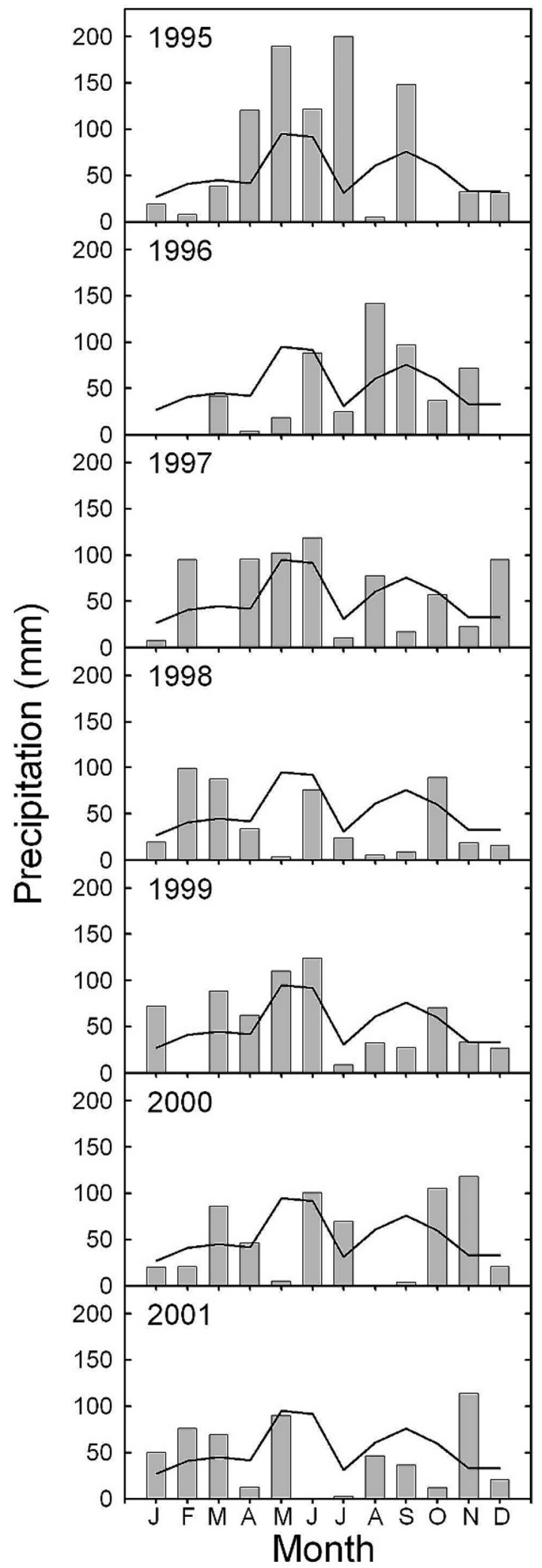

Figure 1. Monthly precipitation (bars) compared to the long-term (30yr) mean monthly precipitation (line) for the Waggoner Experimental Ranch (WER), north central Texas, 1995 to 2001. Precipitation was recorded at several locations on the WER and averaged.

\section{Weaning Percentages}

Overall differences between previous-year conception rate and gross weaning rate exhibited 5-17 percentage unit loss from pregnancy to weaning among years and strategies (Table 3 ). Strategy differences in weaned calf percentages were observed in 1996, where the continuous strategy had greater $(P<0.05)$ weaned calf percentage than the $4: 1 \mathrm{~F}$ and $8: 1 \mathrm{~F}$ strategies. After 1996 there was no difference among strategies in weaned calf percentage.

\section{Weaning Weights}

Weaning weights varied as a complex function of year and grazing strategy (Table 3). Weaning weights were $23 \mathrm{~kg} \cdot$ head $^{-1}$ greater $(P<0.05)$ in the continuous than the $8: 1 \mathrm{~F}$ strategy in 1995 , and were $16.5-29.5 \mathrm{~kg} \cdot \mathrm{head}^{-1}$ greater $(P<0.05)$ in the continuous than all three restoration strategies in 1996. Weaning weights were $10.1-10.5 \mathrm{~kg} \cdot \mathrm{head}^{-1}$ less $(P<0.07)$ in the $8: 1 \mathrm{~F}$ than the continuous strategy in 1999 and 2000 . In other years, weaning weights were similar $(P<0.05)$ among strategies.

\section{WtPEC Responses}

WtPEC varied as a complex function of year and restoration strategy. The greatest WtPEC occurred in 1999 (Table 4). The WtPEC was $23.6 \mathrm{~kg}$ greater $(P<0.05)$ in the continuous (Cont) than the $8: 1 \mathrm{~F}$ strategy in 1995 , and was greater $(P<0.05)$ by $22-35 \mathrm{~kg}$ in the Cont than all three restoration strategies in 1996. From 1998-2001, there were no differences in WtPEC among strategies.

\section{WtPHA Responses}

Overall among years there was a decline in WtPHA from $20.4 \mathrm{~kg} \cdot \mathrm{ha}^{-1}$ in 1995 to $10.6 \mathrm{~kg} \cdot \mathrm{ha}^{-1}$ in 2001 as a result of decreasing stocking rates (Table 4). Prior to a third drought in 2001, the rate of WtPHA decline per year had slowed from 1998 to 2000 , to $13.3 \mathrm{~kg} \cdot \mathrm{ha}^{-1}$ and $12.8 \mathrm{~kg} \cdot \mathrm{ha}^{-1}$, respectively. Among strategies within years, WtPHA was greater $(P<0.05)$ in the continuous than the restoration strategies in 1995 and 1996. In 1997, WtPHA was greater $(P<0.05)$ in the continuous than $4: 1 \mathrm{~F}$ and $4: 1 \mathrm{~F} / \mathrm{H}$ strategies. However, in 1998 , WtPHA was greater $(P<0.05)$ in the $8: 1 \mathrm{~F}$ than the continuous strategy. The WtPHA was comparable between the continuous and restoration strategies from 1999 through 2001.

\section{Supplemental Feeding}

Supplemental feeding levels varied among years and within years among strategies (Table 4). Among years, the annual amount of supplement fed per cow ranged from $35.5 \mathrm{~kg} \cdot$ head $^{-1}$ to $140 \mathrm{~kg} \cdot$ head $^{-1}$ primarily as a function of drought and stocking rate. Low levels of supplemental feed were used to rotate animals among paddocks in the $4: 1 \mathrm{~F}$ and 8:1F strategies and as a result, in the first $2 \mathrm{yr}$ of the experiment, more supplement was fed in these strategies as cattle were adapted to more frequent movements among paddocks. A greater amount of supplemental feed was used in the $8: 1 \mathrm{~F}$ than the continuous strategy in 1999. 
Table 2. Planned burns vs. completed paddock burns on the Kite Camp study, 1996-2000.

\begin{tabular}{|c|c|c|c|}
\hline Burn dates & $\begin{array}{l}\text { Original sched- } \\
\text { ule of paddocks } \\
\text { to be burned }\end{array}$ & $\begin{array}{l}\text { Total } \\
\text { paddocks } \\
\text { burned }\end{array}$ & $\begin{array}{l}\text { Number of } \\
\text { paddocks burned in each } \\
\text { replicate of each system }{ }^{1}\end{array}$ \\
\hline \multirow[t]{3}{*}{$\begin{array}{l}\text { January-March } \\
1996\end{array}$} & \multirow[t]{3}{*}{8} & \multirow[t]{3}{*}{5} & $\begin{array}{l}8: 1 \mathrm{~F} \text { ( } 1 \text { paddock in each of } 2 \\
\text { replicates) }\end{array}$ \\
\hline & & & $\begin{array}{l}\text { 4:1F (1 paddock in replicate } \\
\text { no. 1) }\end{array}$ \\
\hline & & & $\begin{array}{l}\text { 4:1F/H ( } 1 \text { paddock in each of } 2 \\
\text { replicates) }\end{array}$ \\
\hline $\begin{array}{l}\text { January-March } \\
1997\end{array}$ & 8 & 1 & $\begin{array}{l}\text { 4:1F (1 paddock in replicate } \\
\text { no. 2) }\end{array}$ \\
\hline \multirow[t]{2}{*}{$\begin{array}{l}\text { January-March } \\
1998\end{array}$} & \multirow[t]{2}{*}{8} & \multirow[t]{2}{*}{6} & $\begin{array}{l}8: 1 F \text { ( } 2 \text { paddocks in each of } 2 \\
\text { replicates) }\end{array}$ \\
\hline & & & $\begin{array}{l}\text { 4:1F ( } 1 \text { paddock in each of } 2 \\
\text { replicates) }\end{array}$ \\
\hline $\begin{array}{l}\text { January-March } \\
1999^{2}\end{array}$ & 6 & 0 & No fires conducted \\
\hline $\begin{array}{l}\text { January-March } \\
2000\end{array}$ & 6 & 2 & $\begin{array}{l}8: 1 F \text { ( } 1 \text { paddock in each of } 2 \\
\text { replicates) }\end{array}$ \\
\hline Total 1996-2000 & 36 & 14 & \\
\hline
\end{tabular}

18:1F indicates 8-paddock, 1-herd strategy; 4:1, 4-paddock, 1-herd; 4:1F/H, 4-paddock,1herd, fire or herbicide.

${ }^{2}$ Planned burns were reduced from eight to six in 1999 because the method for mesquite control was changed in the $4: 1 \mathrm{~F} / \mathrm{H}$ strategy from fire to herbicides.

\section{DISCUSSION}

In this experiment, livestock responses can be grouped into two phases: an adaptation phase (first $2 \mathrm{yr}$ ) and a postadaptation phase (last $5 \mathrm{yr}$ ). A shift from continuous grazing at low stocking rates (12.1 ha. $\mathrm{AUY}^{-1}$ ) and infrequent (twice annually) animal handling to rotational grazing at higher stocking rates and frequent animal handling (up to 10 times annually) will affect many ecosystem variables, including soils, vegetation, livestock, and associated herbivores, and it might take several years after making substantial management changes for the system to achieve equilibrium to these new conditions (Provenza 2003).

We found no previously published research where prescribed fire was integrated with grazing strategies to limit woody plant encroachment into grasslands. We also did not find research reports of experiments that determined livestock production responses to grazing strategies, prescribed fire, or the combination thereof at landscape scales comparable to commercial livestock production systems of the Southern Great Plains. The majority of previously published rotational grazing research in the Great Plains has quantified animal performance in terms of weight gain in young beef animals grazing considerably smaller management units and experimental pastures during the growing season only (Heitschmidt et al. 1982; Olson and Malechek 1988; McCollum et al. 1999; Derner and Hart 2007; Briske et al. 2008). Prescribed fire has been used in grazing systems in tallgrass prairie in the United States (Knapp et al. 1998; Fuhlendorf and Engle 2004). However, these regions have abundant and consistent grass production and are not dominated by large invasive woody plants. Thus, the number of published data sets for us to compare our results to in terms of year-long cow-calf performance at a landscape scale in mixedgrass communities was limited.

Reproductive performance and weaned calf percentage varied as a function of year more than restoration strategy. Conception rates were lower in the drought years of 1996 and 2000 than the other years of the study. By comparison, Heitschmidt et al. (1990) utilized cow-calf performance in landscapes of 230 ha to 465 ha, and pastures varying in size from 10 ha to 230 ha over a 7 -yr period to quantify the effects of grazing strategy and stocking rates on cattle productivity. These authors concluded there were no differences in conception rate and weaned calf crop between continuous and rotationally grazed systems at heavy stocking rates. Similarly, they reported no difference between continuous and deferred rotation (4-pasture, 3-herd) systems at moderate stocking rates. These authors concluded that stocking rate, not grazing system, influenced reproductive performance. In our study that used a common stocking rate among all restoration strategies within year, we found that weaned calf percentage differed among strategies only in 1996, the year following implementation of the strategies and a year that had severe growing season drought. The resultant weaned calf percentage was 10 percentage units less in the $8: 1 \mathrm{~F}$ than the continuous strategy. We found weaning weight differences occurred as a complex function of year and restoration strategy, where differences were greater in the first $2 \mathrm{yr}$ of the experiment during the adaptation phase that were associated with strategy implementation and drought. In contrast, Heitschmidt et al. (1990) found no year $X$ grazing system interaction and no year effect on weaning weights. In this study, during the initial 2 -yr adaptation period, weaning weights were lower in the strategy that had the greater number of rotation paddocks. In the postadaptation phase, there was no difference in weaning weight between the continuous and 4:1F strategies in 1999 and 2000 , and the $8: 1 \mathrm{~F}$ strategies weaning weight differences were only half what they were in the implementation phase. The larger differences in weaning weight during the first $2 \mathrm{yr}$ of the experiment reflect the complex set of management changes that occurred and the associated behavioral stress of the cattle to these changes (Provenza 2003).

In four of seven years, weaning weights were $23 \mathrm{~kg} \cdot \mathrm{head}^{-1}$ to $10.5 \mathrm{~kg} \cdot \mathrm{head}^{-1}$ less in the $8: 1 \mathrm{~F}$ than the continuous strategy. Heitschmidt et al. (1990) found across a 7-yr period that weaning weights from heavily stocked rotationally grazed systems were less than those in heavily stocked continuously grazed systems of comparable size, though these authors found no year $\times$ grazing system interaction. Results from both experiments point to the sensitivity of calf weaning weights to management strategies and the causes of which have not been clearly determined in either experiment, though continually maintaining animals at $4 \times$ to $8 \times$ stocking densities is implicated. However, after the first $2 \mathrm{yr}$ of the current study, there was no effect of restoration strategies in 3 of the $5 \mathrm{yr}$. In the $2 \mathrm{yr}$ that differences were found, these occurred between the continuous and 8:1F strategies. Collectively, these results suggest weaning weights are more sensitive to stocking rate and managerial skills than integrated grazing and fire strategies. 
Table 3. Effect of strategy on cattle stocking rate (SR), conception rate (CR), weaned calf percentage (WC), and weaning weight (WWT) in each of the four strategies: continuous grazing, no fire (Cont); 4-pasture, 1-herd, with fire (4:1F); 8-pasture, 1-herd, with fire (8:1F); and 4-pasture, 1-herd, fire or herbicide $(4: 1 \mathrm{~F} / \mathrm{H})$, and averaged over all strategies in each year (bold), 1995-2001. AUY indicates animal unit ${ }^{-1} \cdot \mathrm{yr}^{-1}$.

\begin{tabular}{|c|c|c|c|c|c|}
\hline Year & Strategy & SR (ha $\left.\cdot A^{\prime} Y^{-1}\right)$ & CR $(\%)$ & WC (\%) & WWT (kg) \\
\hline \multirow[t]{5}{*}{1995} & & & $\mathbf{9 1 . 0} \pm \mathbf{2 . 5} \mathbf{u}^{1,2}$ & $80.8 \pm 1.6$ uv & $233.9 \pm 3.9 y$ \\
\hline & Cont & $7.39 \pm 0.06$ & $90.1 \pm 1.0$ & $81.5 \pm 0.5$ & $241.5 \pm 0.5 a^{3}$ \\
\hline & $4: 1 \mathrm{~F}$ & $7.63 \pm 0.18$ & $90.1 \pm 1.0$ & $82.5 \pm 0.5$ & $230.5 \pm 1.5 b$ \\
\hline & $8: 1 F$ & $7.28 \pm 0.04$ & $87.1 \pm 7.0$ & $79.5 \pm 5.0$ & $218.5 \pm 8.5 c$ \\
\hline & $4: 1 F / H$ & $7.87 \pm 0.22$ & $89.1 \pm 1.0$ & $79.5 \pm 0.5$ & $245.0 \pm 5.0 \mathrm{a}$ \\
\hline \multirow[t]{5}{*}{1996} & & & $81.0 \pm 4.3 v$ & $77.8 \pm 1.8 v$ & $195.8 \pm 1.5 \mathrm{z}$ \\
\hline & Cont & $7.51 \pm 0.02$ & $80.5 \pm 6.5 a b$ & $83.5 \pm 0.5 \mathrm{a}$ & $212.0 \pm 3.0 \mathrm{a}$ \\
\hline & $4: 1 F$ & $7.79 \pm 0.14$ & $77.0 \pm 5.0 \mathrm{~b}$ & $75.5 \pm 3.5 b$ & $195.5 \pm 0.5 b$ \\
\hline & $8: 1 F$ & $7.49 \pm 0.04$ & $80.5 \pm 3.5 a b$ & $73.5 \pm 2.5 b$ & $193.0 \pm 2.0 b c$ \\
\hline & $4: 1 F / H$ & $8.28 \pm 0.02$ & $86.0 \pm 2.0 \mathrm{a}$ & $79.0 \pm 0.5 a b$ & $182.5 \pm 0.5 c$ \\
\hline \multirow[t]{5}{*}{1997} & & & $90.4 \pm 1.8 \mathrm{u}$ & $66.9 \pm 1.9 \mathrm{w}$ & $251.0 \pm 2.6 w$ \\
\hline & Cont & $11.01 \pm 0.04$ & $88.5 \pm 1.5$ & $70.5 \pm 1.5$ & $252.5 \pm 4.5$ \\
\hline & $4: 1 F$ & $11.23 \pm 0.02$ & $91.5 \pm 2.5$ & $64.5 \pm 3.5$ & $246.0 \pm 1.0$ \\
\hline & $8: 1 F$ & $11.33 \pm 0.04$ & $90.5 \pm 1.5$ & $65.5 \pm 1.5$ & $253.4 \pm 2.5$ \\
\hline & $4: 1 F / H$ & $12.10 \pm 0.04$ & $91.0 \pm 1.5$ & $67.0 \pm 1.0$ & $252.0 \pm 2.5$ \\
\hline \multirow[t]{5}{*}{1998} & & & $87.6 \pm 2.1 \mathrm{uv}$ & $81.6 \pm 2.4 u$ & $230.4 \pm 4.4 y$ \\
\hline & Cont & $12.18 \pm 0.04$ & $86.5 \pm 3.5$ & $79.0 \pm 1.0$ & $230.5 \pm 5.5$ \\
\hline & $4: 1 F$ & $12.24 \pm 0.02$ & $87.5 \pm 2.5$ & $83.0 \pm 3.0$ & $231.5 \pm 6.5$ \\
\hline & $8: 1 F$ & $12.16 \pm 0.02$ & $90.5 \pm 1.5$ & $84.5 \pm 1.5$ & $231.0 \pm 1.0$ \\
\hline & $4: 1 F / H$ & $13.56 \pm 0.00$ & $86.0 \pm 1.0$ & $80.0 \pm 4.0$ & $228.5 \pm 4.5$ \\
\hline \multirow[t]{5}{*}{1999} & & & $90.4 \pm 2.9 u$ & $81.9 \pm 3.1 \mathrm{u}$ & $261.6 \pm 4.4 v$ \\
\hline & Cont & $12.81 \pm 0.14$ & $89.5 \pm 4.5$ & $79.5 \pm 3.5$ & $264.5 \pm 5.5 a b^{4}$ \\
\hline & $4: 1 F$ & $12.69 \pm 0.02$ & $91.0 \pm 1.0$ & $81.0 \pm 3.0$ & $259.5 \pm 0.5 a b$ \\
\hline & $8: 1 F$ & $12.55 \pm 0.24$ & $91.5 \pm 1.5$ & $85.0 \pm 2.0$ & $254.0 \pm 10.0 \mathrm{~b}$ \\
\hline & $4: 1 F / H$ & $13.27 \pm 0.04$ & $89.5 \pm 4.5$ & $82.0 \pm 4.0$ & $268.5 \pm 1.5 \mathrm{a}$ \\
\hline \multirow[t]{5}{*}{2000} & & & $84.6 \pm 3.1 v$ & $78.5 \pm 2.3 v w$ & $267.8 \pm 7.5 \mathrm{u}$ \\
\hline & Cont & $15.32 \pm 0.10$ & $82.5 \pm 2.5$ & $76.5 \pm 1.5$ & $273.5 \pm 9.5 \mathrm{a}^{5}$ \\
\hline & $4: 1 F$ & $15.42 \pm 1.09$ & $85.0 \pm 4.0$ & $80.5 \pm 3.5$ & $265.0 \pm 9.0 \mathrm{ab}$ \\
\hline & $8: 1 F$ & $13.70 \pm 0.14$ & $84.5 \pm 5.5$ & $77.5 \pm 3.5$ & $263.4 \pm 5.0 \mathrm{~b}$ \\
\hline & $4: 1 F / H$ & $15.46 \pm 0.36$ & $86.5 \pm 0.5$ & $79.5 \pm 0.5$ & $269.5 \pm 6.5 \mathrm{ab}$ \\
\hline \multirow[t]{5}{*}{2001} & & & $87.6 \pm 2.9$ uv & $77.3 \pm 3.5 w$ & $242.6 \pm 2.1 \times$ \\
\hline & Cont & $15.14 \pm 0.08$ & $89.0 \pm 7.0$ & $79.5 \pm 9.5$ & $243.5 \pm 3.5$ \\
\hline & $4: 1 \mathrm{~F}$ & $16.21 \pm 0.02$ & $87.0 \pm 1.0$ & $77.0 \pm 1.0$ & $245.0 \pm 2.0$ \\
\hline & $8: 1 F$ & $15.38 \pm 0.36$ & $88.5 \pm 0.5$ & $74.5 \pm 2.5$ & $243.0 \pm 1.0$ \\
\hline & $4: 1 F / H$ & $16.05 \pm 0.42$ & $86.0 \pm 3.0$ & $78.0 \pm 1.0$ & $239.0 \pm 2.0$ \\
\hline
\end{tabular}

\footnotetext{
${ }^{1}$ Means ( \pm standard error).

${ }^{2}$ Lowercase letters uvwxyz indicate that means within a variable and among years without a common letter differ at $P<0.05$ unless otherwise noted in table.

${ }^{3}$ Lowercase letters abcdef indicate that means within a variable and year without a common letter differ at $P<0.05$ unless otherwise noted in table.

${ }^{4} P<0.08$.

${ }^{5} P<0.07$.
}

Supplemental feeding levels were appreciably greater in the $4: 1 \mathrm{~F}$ and $8: 1 \mathrm{~F}$ in the first $2 \mathrm{yr}$ of the experiment as a result of utilizing low levels of supplemental feed to assist in rotating animals from paddock to paddock throughout the year. Supplementation outside the 90 - to $100-\mathrm{d}$ winter supplementation period would have had minimal effects on livestock performance. Conceivably, supplementation for the balance of the year $(260+d)$ would increase forage available per animal in a 1:1 ratio to the amount of supplements fed resulting in an additional $12-34 \mathrm{~kg}$ dry matter $\cdot \operatorname{cow}^{-1} \cdot 250 \mathrm{~d}^{-1}$, a negligible addition of diet dry matter.

Heitschmidt et al. (1990) found that year had a greater affect on WtPEC than did grazing systems. They reported no difference in WtPEC between heavy-stocked continuous and heavy-stocked rotational grazing systems. In this study during the initial 2-yr adaptation period, we found that WtPEC was greater in the continuous strategy than the 8:1F strategy in the first year and was greater in the continuous strategy than all three restoration strategies in the second year.

Heitschmidt et al. (1990) reported finding no year $\times$ grazing system interaction in WtPHA. In our experiment, higher rates of stocking in the first $2 \mathrm{yr}$ led to greater WtPHA as would be expected. In year one, only the $8: 1 \mathrm{~F}$ and continuous strategy differed whereas in year two, the continuous strategy exhibited greater WtPHA than all other strategies. After the first $2 \mathrm{yr}$, WtPHA response in the $8: 1 \mathrm{~F}$ strategy was similar to or greater 
Table 4. Effect of strategy on weight of calf per exposed cow (WtPEC), weight of calf $\cdot$ ha $^{-1}(\mathrm{WtPHA})$, and supplement fed $\cdot$ head ${ }^{-1}(\mathrm{SUPP})$ in each of the four strategies: continuous grazing, no fire (Cont); 4-pasture, 1-herd, with fire (4:1F); 8-pasture, 1-herd, with fire (8:1F); and 4-pasture, 1-herd, fire or herbicide $(4: 1 \mathrm{~F} / \mathrm{H})$, and averaged over all strategies in each year (bold), 1995-2001.

\begin{tabular}{|c|c|c|c|c|}
\hline Year & Strategy & WtPEC (kg) & WtPHA (kg) & SUPP $\left(\mathrm{kg} \cdot\right.$ head $\left.^{-1}\right)$ \\
\hline \multirow[t]{5}{*}{1995} & & $187.1 \pm 2.8 v^{1,2}$ & $20.4 \pm 0.5 \mathrm{u}$ & $35.5 \pm 2.1 \mathrm{y}$ \\
\hline & Cont & $197.1 \pm 1.6 \mathrm{a}^{3}$ & $21.8 \pm 0.4 \mathrm{a}$ & $27.5 \pm 1.5 b$ \\
\hline & $4: 1 F$ & $190.0 \pm 1.8 a b$ & $20.2 \pm 0.3 b$ & $38.5 \pm 2.5 \mathrm{a}$ \\
\hline & $8: 1 F$ & $173.5 \pm 7.1 \mathrm{~b}$ & $19.6 \pm 0.8 b$ & $47.5 \pm 1.5 \mathrm{a}$ \\
\hline & $4: 1 \mathrm{~F} / \mathrm{H}$ & $187.8 \pm 0.7 a b$ & $20.2 \pm 0.1 \mathrm{~b}$ & $28.5 \pm 7.6 \mathrm{~b}$ \\
\hline \multirow[t]{5}{*}{1996} & & $152.4 \pm 4.2 \times$ & $18.2 \pm 0.5 v$ & $140.0 \pm 13.1 \mathrm{u}$ \\
\hline & Cont & $176.6 \pm 2.1 \mathrm{a}$ & $22.1 \pm 0.4 \mathrm{a}$ & $120.5 \pm 1.5 b$ \\
\hline & $4: 1 F$ & $147.8 \pm 7.3 \mathrm{~b}$ & $18.4 \pm 0.6 b$ & $146.5 \pm 26.5 \mathrm{a}$ \\
\hline & $8: 1 F$ & $141.4 \pm 6.4 b$ & $18.9 \pm 0.9 b$ & $154.5 \pm 18.5 \mathrm{a}$ \\
\hline & 4:1F/H & $144.1 \pm 1.0 \mathrm{~b}$ & $16.7 \pm 0.1 \mathrm{c}$ & $138.5 \pm 5.5 \mathrm{ab}$ \\
\hline \multirow[t]{5}{*}{1997} & & $168.0 \pm 4.7 \mathrm{w}$ & $15.3 \pm 0.4 \mathrm{w}$ & $68.9 \pm 1.9 \times$ \\
\hline & Cont & $177.3 \pm 2.3 a^{4}$ & $16.1 \pm 0.1 \mathrm{a}$ & $78.0 \pm 3.0$ \\
\hline & $4: 1 F$ & $158.2 \pm 7.3 \mathrm{~b}$ & $14.8 \pm 0.7 \mathrm{~b}$ & $60.5 \pm 3.5$ \\
\hline & $8: 1 F$ & $166.8 \pm 5.0 a b$ & $15.4 \pm 0.5 \mathrm{ab}$ & $68.0 \pm 0.1$ \\
\hline & $4: 1 F / H$ & $169.6 \pm 4.1 a b$ & $14.9 \pm 0.4 b$ & $69.0 \pm 1.0$ \\
\hline \multirow[t]{5}{*}{1998} & & $187.3 \pm 4.4 v$ & $13.3 \pm 0.3 x^{5}$ & $102.1 \pm 5.1 v$ \\
\hline & Cont & $180.7 \pm 0.2$ & $12.7 \pm 0.1 b$ & $99.0 \pm 3.0$ \\
\hline & $4: 1 F$ & $191.4 \pm 2.3$ & $13.5 \pm 0.1 \mathrm{ab}$ & $102.0 \pm 3.0$ \\
\hline & $8: 1 F$ & $194.0 \pm 2.3$ & $14.1 \pm 0.2 \mathrm{a}$ & $99.5 \pm 2.5$ \\
\hline & 4:1F/H & $183.2 \pm 12.7$ & $13.1 \pm 1.0 \mathrm{ab}$ & $108.0 \pm 12.0$ \\
\hline \multirow[t]{5}{*}{1999} & & $214.2 \pm 11.3 u$ & $12.8 \pm 0.6 x y$ & $89.3 \pm 2.9 w$ \\
\hline & Cont & $210.2 \pm 14.5$ & $12.6 \pm 0.7$ & $79.0 \pm 0.7 \mathrm{~b}$ \\
\hline & $4: 1 \mathrm{~F}$ & $210.0 \pm 7.7$ & $12.7 \pm 0.7$ & $89.0 \pm 5.0 a b$ \\
\hline & $8: 1 F$ & $216.0 \pm 12.9$ & $13.4 \pm 0.7$ & $99.5 \pm 1.5 \mathrm{a}$ \\
\hline & 4:1F/H & $220.5 \pm 9.9$ & $12.7 \pm 0.2$ & $89.5 \pm 4.5 \mathrm{ab}$ \\
\hline \multirow[t]{5}{*}{2000} & & $210.3 \pm 7.6 \mathrm{uv}$ & $12.8 \pm 0.4 y$ & $92.4 \pm 3.9 v w$ \\
\hline & Cont & $210.0 \pm 11.4$ & $12.7 \pm 0.4 a b$ & $85.0 \pm 1.0$ \\
\hline & $4: 1 F$ & $213.0 \pm 1.6$ & $12.6 \pm 0.6 a b$ & $91.0 \pm 4.0$ \\
\hline & $8: 1 F$ & $204.0 \pm 12.7$ & $13.5 \pm 0.2 \mathrm{a}^{\mathrm{b}}$ & $97.0 \pm 6.0$ \\
\hline & 4:1F/H & $214.1 \pm 4.6$ & $12.3 \pm 0.5 b$ & $96.5 \pm 4.5$ \\
\hline \multirow[t]{5}{*}{2001} & & $177.0 \pm 8.6 \mathrm{v}$ & $10.6 \pm 0.5 z$ & $132.6 \pm 6.1 \mathrm{u}$ \\
\hline & Cont & $193.9 \pm 2.5$ & $11.0 \pm 0.7$ & $134.0 \pm 6.0$ \\
\hline & $4: 1 F$ & $189.6 \pm 1.4$ & $10.4 \pm 0.3$ & $133.5 \pm 4.5$ \\
\hline & $8: 1 F$ & $181.4 \pm 6.9$ & $10.5 \pm 0.6$ & $140.5 \pm 2.5$ \\
\hline & $4: 1 F / H$ & $185.9 \pm 1.4$ & $10.4 \pm 0.6$ & $122.5 \pm 11.5$ \\
\hline
\end{tabular}

\footnotetext{
${ }^{1}$ Means ( \pm standard error).

${ }^{2}$ Lowercase letters uvwxyz indicate that means within a variable and among years without a common letter differ at $P<0.05$ unless otherwise noted in table.

${ }^{3}$ Lowercase letters abcdef indicate that means within a variable and year without a common letter differ at $P<0.05$ unless otherwise noted in table.

${ }^{4} p<0.08$.

${ }^{5} P<0.07$.
}

than the other strategies. This progression toward similarity in WtPHA among strategies through time is consistent with the other indices of reproductive performance and cattle productivity. Our conclusion that at landscape scales, yearly variations in precipitation and stocking rates affect cattle productivity more than restoration strategy, is consistent with the results of Derner and Hart (2007) and Heitschmidt et al. (1990). At appropriate stocking rates, integrated rotational grazing and prescribed burning strategies allowed for the inclusion of prescribed burning for mesquite mitigation with minimal impacts cattle production or requiring use of land areas outside of the strategy to provide for pre- and postburn deferment.
The research conducted in this experiment evaluated livestock responses to ranch-scale restoration strategies involving integration of grazing management and prescribed burning on Southern Great Plains rangelands that had become dominated by woody plant (mesquite) populations. The strategies employed were designed to reduce impacts of woody plant encroachment, while simultaneously providing sustainable levels of livestock production. Fire was the primary woody plant management option and the strategies were designed to internalize all pre- and postfire grazing deferments while maintaining a moderate stocking rate for the total land area within each strategy. Stocking rates among strategies within years were relatively constant and 
only varied among years based on precipitation and annual herbaceous productivity.

When moving from a single-herd, single-pasture strategy to a single-herd, multipaddock strategy, we found that animal production was greater in the $4: 1 \mathrm{~F}$ than the $8: 1 \mathrm{~F}$ strategy during the adaptation phase suggesting this strategy would be advisable before progressing to an 8-pasture strategy. A gradual change from single herd, single pasture to a single herd, multipaddock provides management and livestock time to adapt to the different management and minimizes losses in livestock production. The need cannot be overstated for personnel unfamiliar with rotational grazing and prescribed burning to develop skills and change their management approach for successful adoption of integrated rotational grazing and prescribed fire strategies.

\section{MANAGEMENT IMPLICATIONS}

Animal performances in the postadaptation phase of both the $8: 1 \mathrm{~F}$ and $4: 1 \mathrm{~F}$ strategies were similar to the continuous-grazed strategy. This occurred even when effective stocking rates in these strategies were de facto $8 \%$ to $17 \%$ greater in terms of the strategy and cattle herd because that proportion of grazing days was removed in order to provide deferment associated with using fire. Thus, this study demonstrated that pre- and postfire grazing deferment can be internalized within these moderately stocked strategies with minimal loss in animal performance once management and animals adapt to the strategy.

The data generated in this study provided comprehensive whole-system responses required to calculate the stocking levels and grazing and fire management necessary to determine the potential of prescribed fire to reduce mesquite and to simulate the economic consequences of using fire with different management combinations (Van Tassell and Conner 1986; Teague et al. 2008b). The use of results from a ranch-size field experiment ensures that spatial-temporal interactions occurring at ranch-scale environments were captured, and as such, provides increased confidence in the veracity of the results and their relevance for ranch-scale rangeland management decisions.

\section{ACKNOWLEDGMENTS}

The authors gratefully acknowledge the facilities and livestock made available by W. T. Waggoner Estate. We thank Rob Borchardt, Cody Bradley, Michel Bryant, Justin Clarey, Bob Cross, Diane Conover, David Echels, Joelyn Foy, Russell Fritsch, Doug Fulford, Tracy Gwaltney, Jason Hohlt, Jay Hunt, Eli Ornelas, Gerral Schulz, Riley Shoaf, Gina Spratt, Dustin Stacey, John Todd, Doug Tolleson, Tim Tunnel, Dan Vasquez, and Jan Worrall for scientific and technical assistance. The project is also indebted to the competent inputs of the Waggoner Ranch staff, particularly Weldon Hawley, Dee Robinson, and Anne Pilcher.

\section{LITERATURE CITED}

Ansley, R. J., and M. J. Castellano. 2007. Texas wintergrass and buffalograss response to seasonal fires and clipping. Rangeland Ecology and Management 60:154-164
Ansley, R. J., And P. W. Jacoby. 1998. Manipulation of fire intensity to achieve mesquite management goals in north Texas. In: T. L. Pruden and L. A. Brennan [EDS.]. Fire in ecosystem management: shifting the paradigm from suppression to prescription. Proceedings of the Tall Timbers Fire Ecology Conference No. 20; 7-10 May 1996; Boise, ID, USA. Lawrence, KS, USA: Allen Press. p. 195-204.

Ansley, R. J., D. L. Jones, T. R. Tunnell, B. A. Kramp, and P. W. Jacoby. 1998. Honey mesquite canopy responses to single winter fires: relation to fine fuel, weather and fire temperature. International Journal of Wildland Fire 8:241-252.

Ansley, R. J., B. A. Kramp, and D. L. Jones. 2003. Converting mesquite thickets to savanna through foliage modification with clopyralid. Journal of Range Management 56:72-80.

Ansley, R. J., W. E. Pinchak, W. R. Teague, B. A. Kramp, and K. Barnett. 2010. Integrated grazing and prescribed fire restoration strategies in a mesquite savanna: II. mesquite landscape cover responses. Rangeland Ecology and Management 63:286-297.

Ansley, R. J., W. E. Pinchak, W. R. Teague, B. A. Kramp, D. L. Jones, and P. W. Jacoby. 2004. Long-term grass yields following chemical control of honey mesquite. Journal of Range Management 57:49-57.

Archer, S., D. S. Schimel, and E. A. Holland. 1995. Mechanisms of shrubland expansion: land use, climate or $\mathrm{CO}_{2}$ ? Climatic Change 29:91-99.

Archibald, S., W. J. Bond, W. D. Stock, and D. H. K. Fairbanks. 2005. Shaping the landscape: fire-grazer interactions in an African savanna. Ecological Applications 15(1):96-109.

Arthington, D., F. M. Roka, J. J. Mullahey, S. W. Coleman, R. M. Muchovej, L. O. LoLLIS, AND D. HITCHCOCK. 2007. Integrating ranch forage production, cattle performance, and economics in ranch management systems for southern Florida. Rangeland Ecology and Management 60:12-18.

Asmer, G. P., S. R. Archer, R. F. Hughes, R. J. Ansley, and C. A. Wessman. 2003. Net changes in regional woody vegetation cover and carbon storage in Texas drylands, 1937-1999. Global Change Biology 9:316-335.

Bedunah, D. J., and R. E. Sosebee. 1984. Forage response of a mesquitebuffalograss community following range rehabilitation. Journal of Range Management 37:483-487.

Briske, D. D., J. D. Derner, J. R. Brown, S. D. Fuhlendorf, W. R. Teague, K. M. Havstad, R. L. Gilleen, A. J. Ash, and W. D. Willms. 2008. Rotational grazing on rangelands: reconciliation of perception and experimental evidence. Rangeland Ecology and Management 61:3-17.

Derner, J. D., And R. H. Hart. 2007. Grazing-induced modifications to peak standing crop in northern mixed grass prairie. Rangeland Ecology and Management 60:270-276.

Funlendorf, S. D., And D. M. Engle. 2004. Application of the fire-grazing interaction to restore a shifting mosaic on tallgrass prairie. Journal of Applied Ecology 41:604-614

Heitschmidt, R. K., S. K. Canon, J. R. Conner, W. E. Pinchak, S. L. Dowhower, and J. W. WALKER. 1990. Effects of year-long continuous, deferred rotation, and short duration grazing treatments on cow/calf production at the Texas Experimental Ranch. Journal of Agricultural Production 3:92-99.

Heitschmidt, R. K., J. M. Frasure, D. L. Price, and L. R. Rittenhouse. 1982. Short duration grazing at the Texas Experimental Ranch: weight gain of growing heifers. Journal of Range Management 35:375-379.

Knapp, A. K., J. M. Briggs, J. M. Blair, and C. L. Turner. 1998. Patterns and controls of aboveground net primary production in Tallgrass prairie. In: A. K. Knapp, J. M. Briggs, D. C. Hartnett, and S. L. Collins [EDS.]. Grassland dynamicslong term ecological research in Tallgrass prairie. New York, NY, USA: Oxford University Press. p. 193-221.

Kothmann, M. M., and R. T. Hinnant. 1999. The grazing manager for windows. College Station, TX, USA: Department of Rangeland Ecology and Management, Texas A\&M University, computer program manual 40.

McCollum, F. T., III, R. L. Gillen, B. R. Karges, and M. E. Hodges. 1999. Stocker cattle response to grazing management in the tallgrass prairie. Journal of Range Management 52:120-126.

McDaniel, K. C., J. H. Brock, and R. H. HaAs. 1982. Changes in vegetation and grazing capacity following honey mesquite control. Journal of Range Management 35:551-557. 
McGinty, A. 2004. Chemical weed and brush control—a Texas range scientist's viewpoint. In: W. T. Hamilton, A. McGinty, D. N. Ueckert, C. W. Hanselka, and M. R. Lee [EDS.]. Brush management-past, present and future. College Station, TX, USA: Texas A\&M University Press. p. 76-84.

Mitchell, R., S. Whisenant, and R. Sosebee. 2004. Chemical brush management-a paradigm shift. In: W. T. Hamilton, A. McGinty, D. N. Ueckert, C. W. Hanselka, and M. R. Lee [EDS.]. Brush management-past, present and future. College Station, TX, USA: Texas A\&M University Press. p. 67-75.

OLSON, K. C., AND J. C. MALECHEK. 1988. Heifer nutrition and growth on short duration grazed crested wheatgrass. Journal of Range Management 41:259-263.

ProvenzA, F. D. 2003. Foraging behavior: managing to survive in a world of change. Utah Agricultural Experiment Station. Available at: http://behave.net/products/ booklet.html. Accessed 17 May 2008.

SAS [computer program]. 2002. SAS Version 9.1 for Windows. Cary, NC, USA: SAS Institute, Inc.

Scifres, C. J., and W. T. Hamilton. 1993. Prescribed burning for brushland management: the south Texas example. College Station, TX, USA: Texas A\&M University Press. $246 p$.

Teague, W. R., R. J. Ansley, W. E. Pinchak, S. L. Dowhower, S. A. Gerrard, and J. A. Waggoner. 2008a. Interannual herbaceous biomass response to increasing honey mesquite cover on two soils. Rangeland Ecology and Management 61:496-508.
Teague, W. R., S. L. Dowhower, R. J. Ansley, W. E. Pinchak, and J. A. Waggoner. 2010. Integrated grazing and prescribed fire restoration strategies in a mesquite savanna: I. vegetation responses. Rangeland Ecology and Management 63:275-285.

Teague, W. R., W. E. Grant, U. P. Kreuter, H. Diaz-Solis, S. Dube, M. M. Kothmann, W. E. Pinchak, and R. J. Ansley. 2008b. An ecological economic simulation model for assessing fire and grazing management effects on mesquite rangelands in Texas. Ecological Economics 64:612-625.

VALONE, T. J. 2003. Examination of interaction effects of multiple disturbances on an arid plant community. Southwestern Naturalist 48:481-490.

Valone, T. J., and D. A. Kelt. 1999. Fire and grazing in a shrub invaded arid grassland community: independent or interactive effects? Journal of Arid Environments 42:15-28.

Van Auken, 0. W. 2000. Shrub invasions of North American semiarid grasslands. Annual Review of Ecology and Systematics 31:197-215.

Van Tassell, C. W., and J. R. Conner. 1986. An economic analysis of brush control practices and grazing systems in the Rolling Plains of Texas. MP-1619. College Station, TX, USA: Texas Agricultural Experiment Station, Texas A\&M University. $13 p$.

Wright, H. A., AND A. W. Balley. 1982. Fire ecology. New York, NY, USA: John Wiley \& Sons. 501 p. 